Supplement of Hydrol. Earth Syst. Sci., 23, 2379-2400, 2019

https://doi.org/10.5194/hess-23-2379-2019-supplement

(c) Author(s) 2019. This work is distributed under

the Creative Commons Attribution 4.0 License.

(c) (1)

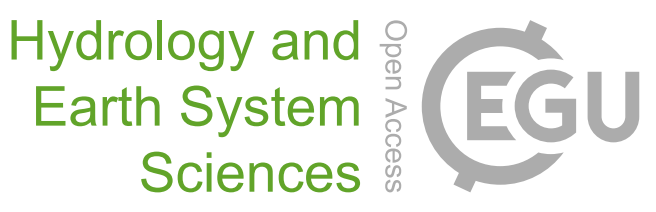

Supplement of

\title{
Contribution of low-frequency climatic-oceanic oscillations to streamflow variability in small, coastal rivers of the Sierra Nevada de Santa Marta (Colombia)
}

Juan Camilo Restrepo et al.

Correspondence to: Juan Camilo Restrepo (restrepocj@uninorte.edu.co)

The copyright of individual parts of the supplement might differ from the CC BY 4.0 License. 

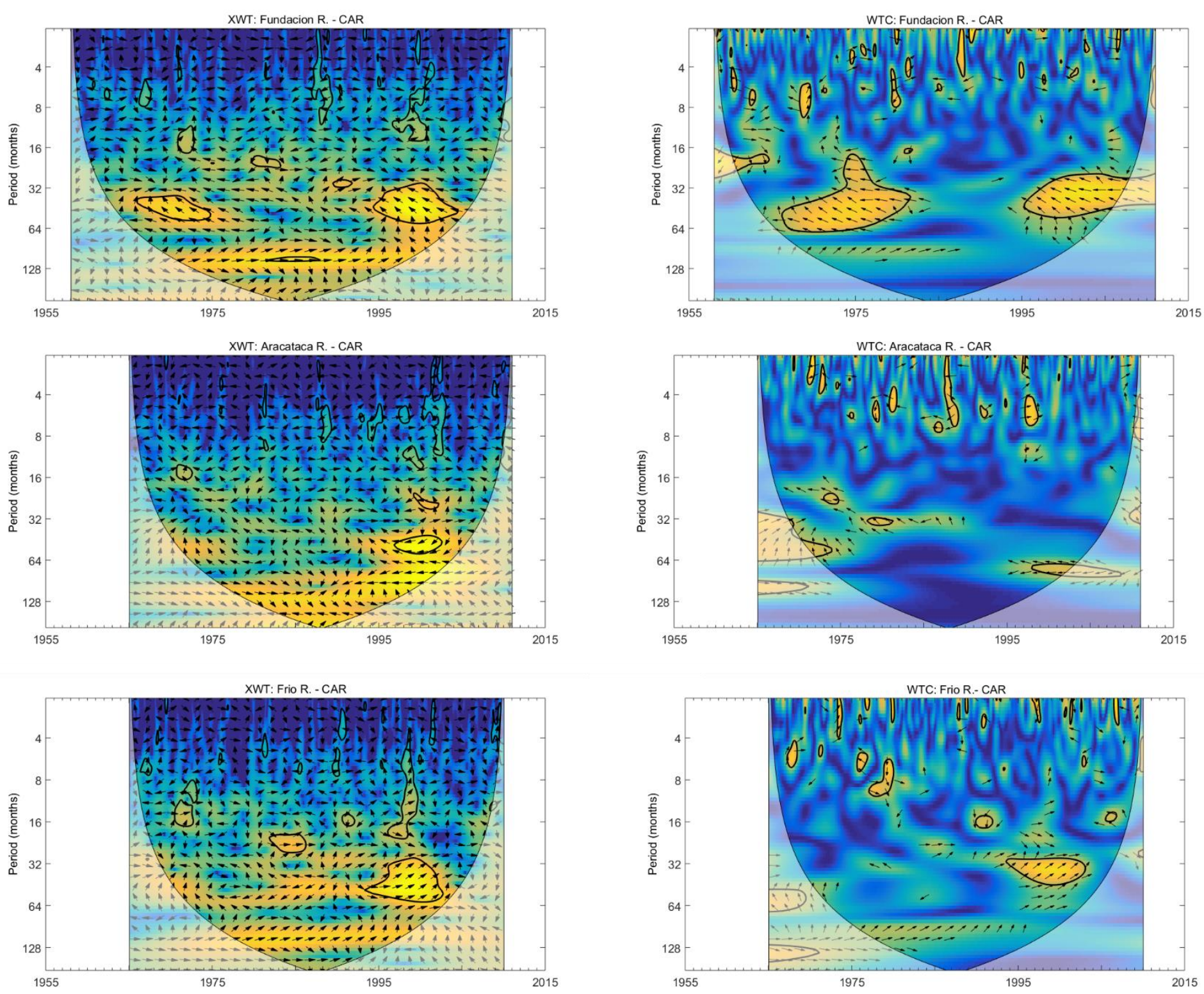

Fig. S1. Cross Wavelet Transform (XWT) and Wavelet Coherence (WTC) between CAR and the Fundación, Aracataca, and Frío rivers. 

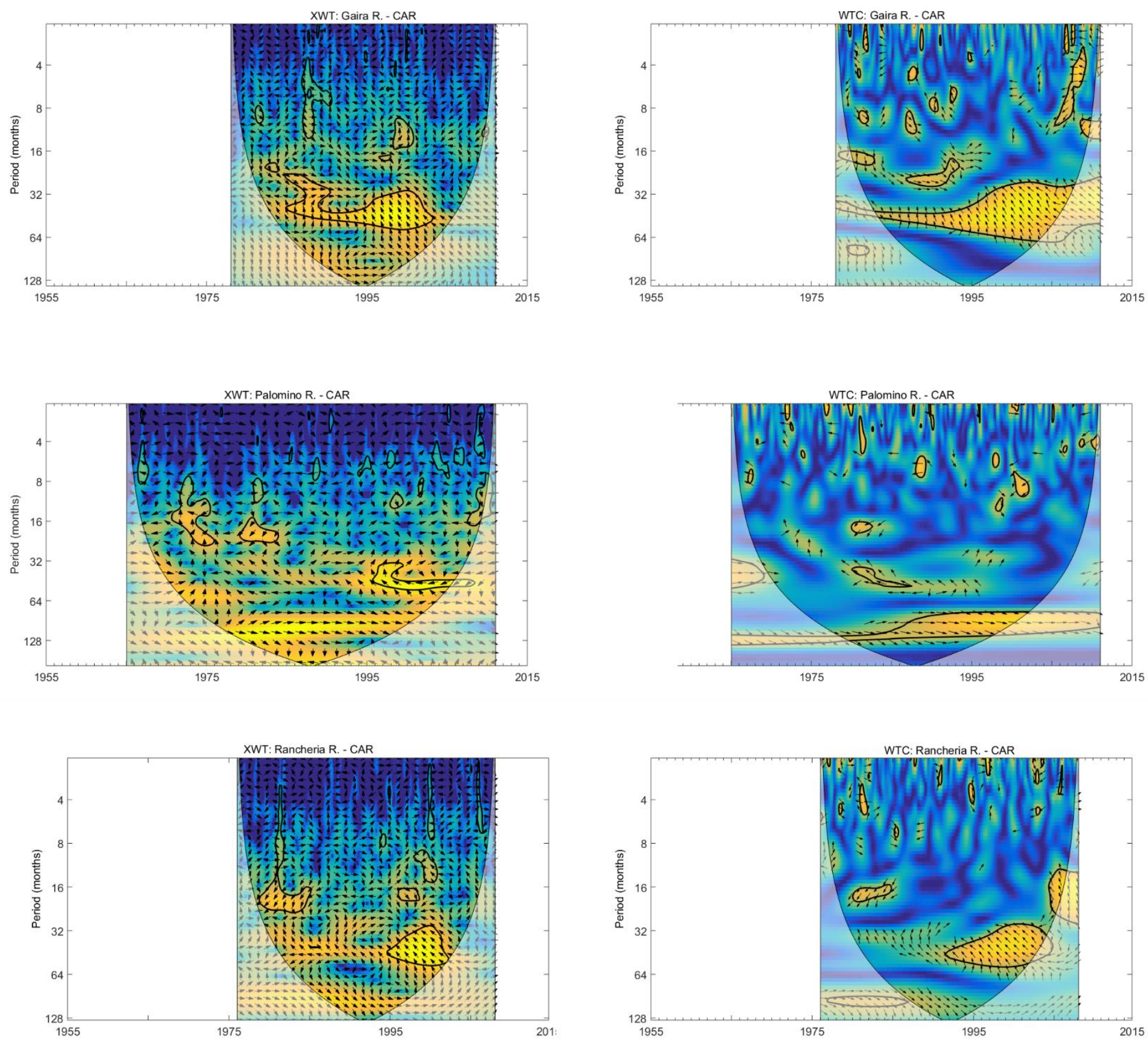

Fig. S2. Cross Wavelet Transform (XWT) and Wavelet Coherence (WTC) between CAR and the Gaira, Palomino, and Ranchería rivers. 

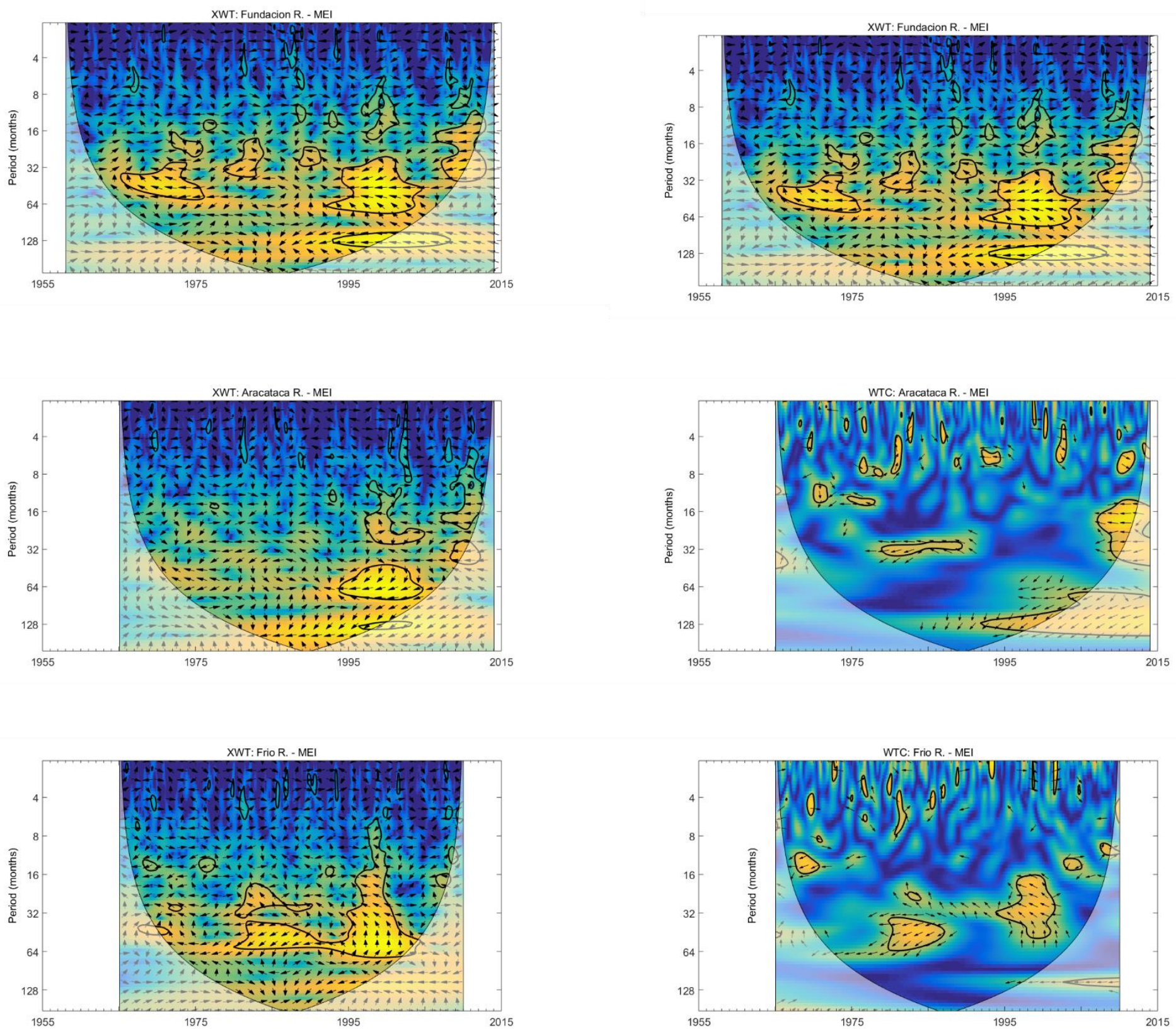

Fig. S3. Cross Wavelet Transform (XWT) and Wavelet Coherence (WTC) between MEI and the Fundación, Aracataca, and Frío rivers. 

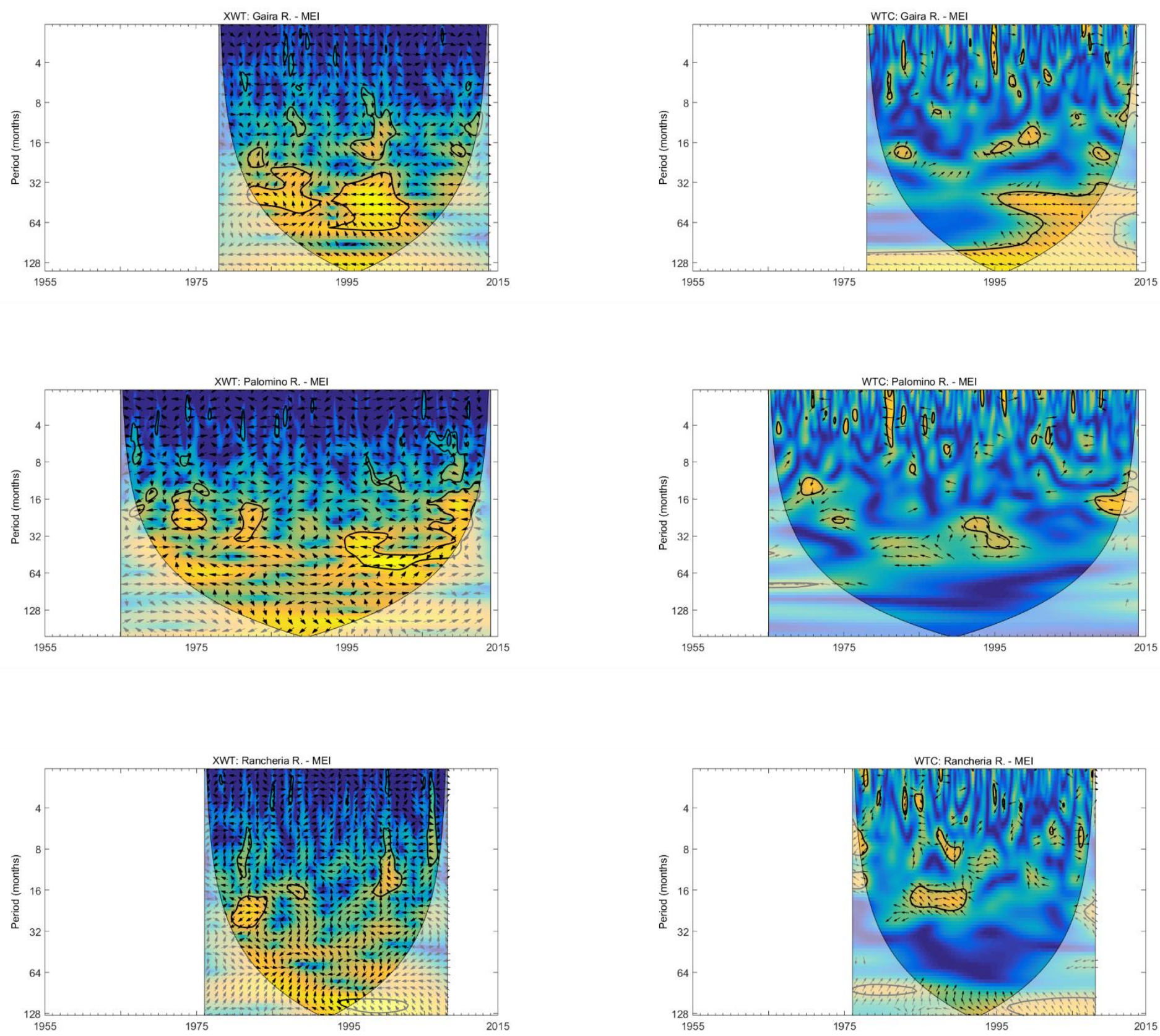

Fig. S4. Cross Wavelet Transform (XWT) and Wavelet Coherence (WTC) between MEI and the Gaira, Palomino, and Ranchería rivers. 

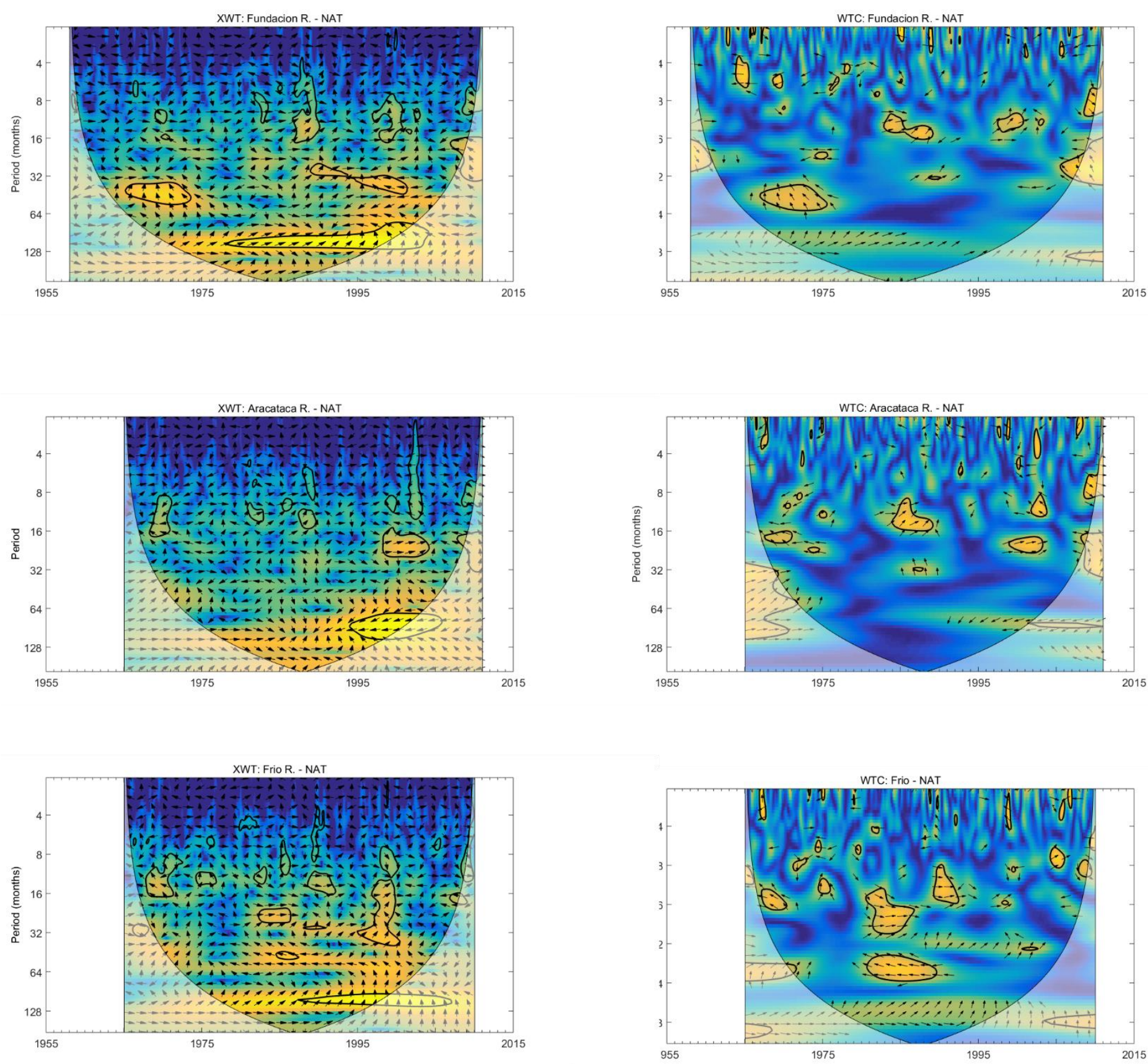

Fig. S5. Cross Wavelet Transform (XWT) and Wavelet Coherence (WTC) between NAT and the Fundación, Aracataca, and Frío rivers. 

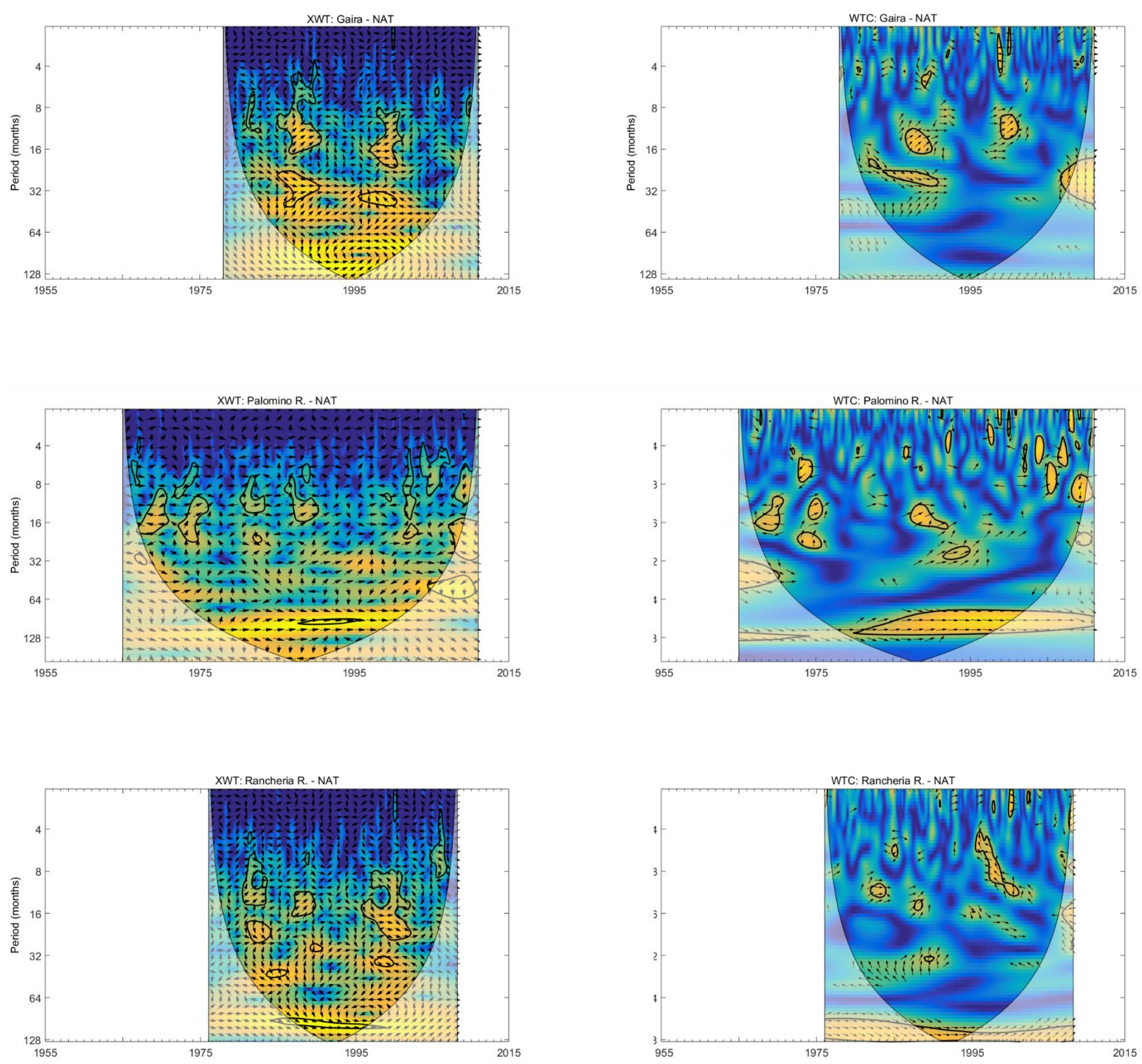

Fig. S6. Cross Wavelet Transform (XWT) and Wavelet Coherence (WTC) between NAT and the Gaira, Palomino, and Ranchería rivers. 

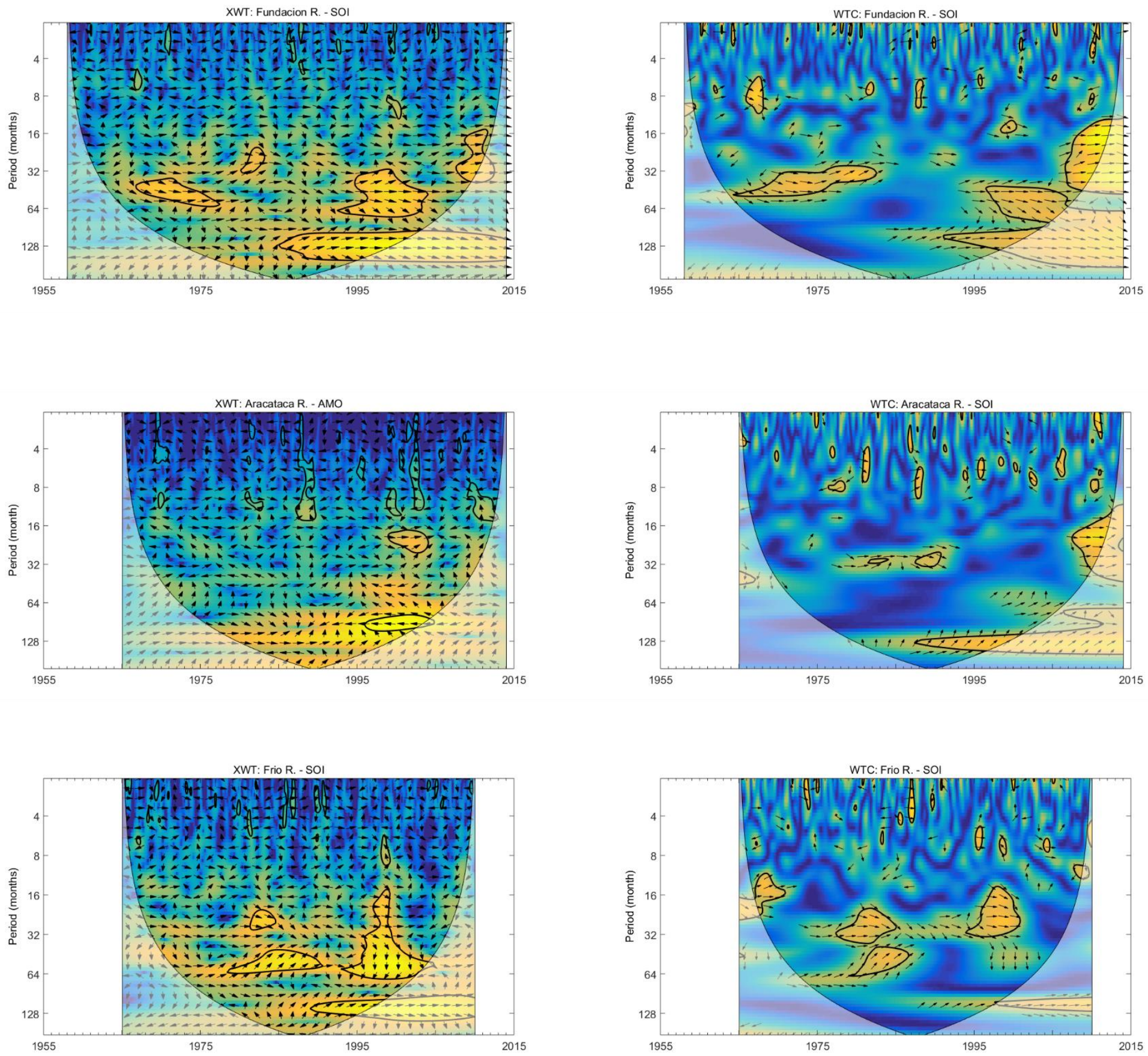

Fig. S7. Cross Wavelet Transform (XWT) and Wavelet Coherence (WTC) between SOI and the Fundación, Aracataca, and Frío rivers. 

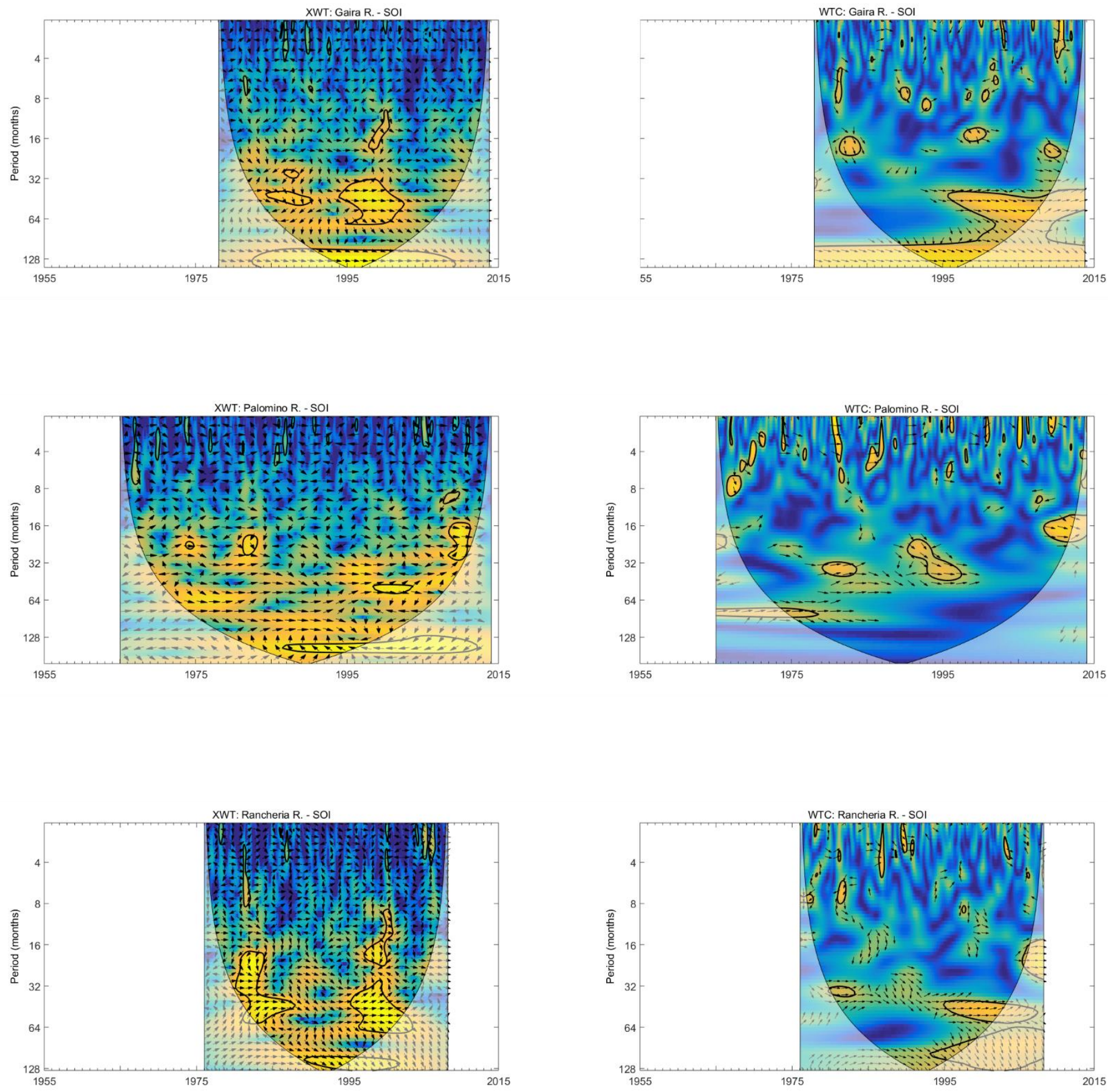

Fig. S8. Cross Wavelet Transform (XWT) and Wavelet Coherence (WTC) between SOI and the Gaira, Palomino, and Ranchería rivers. 

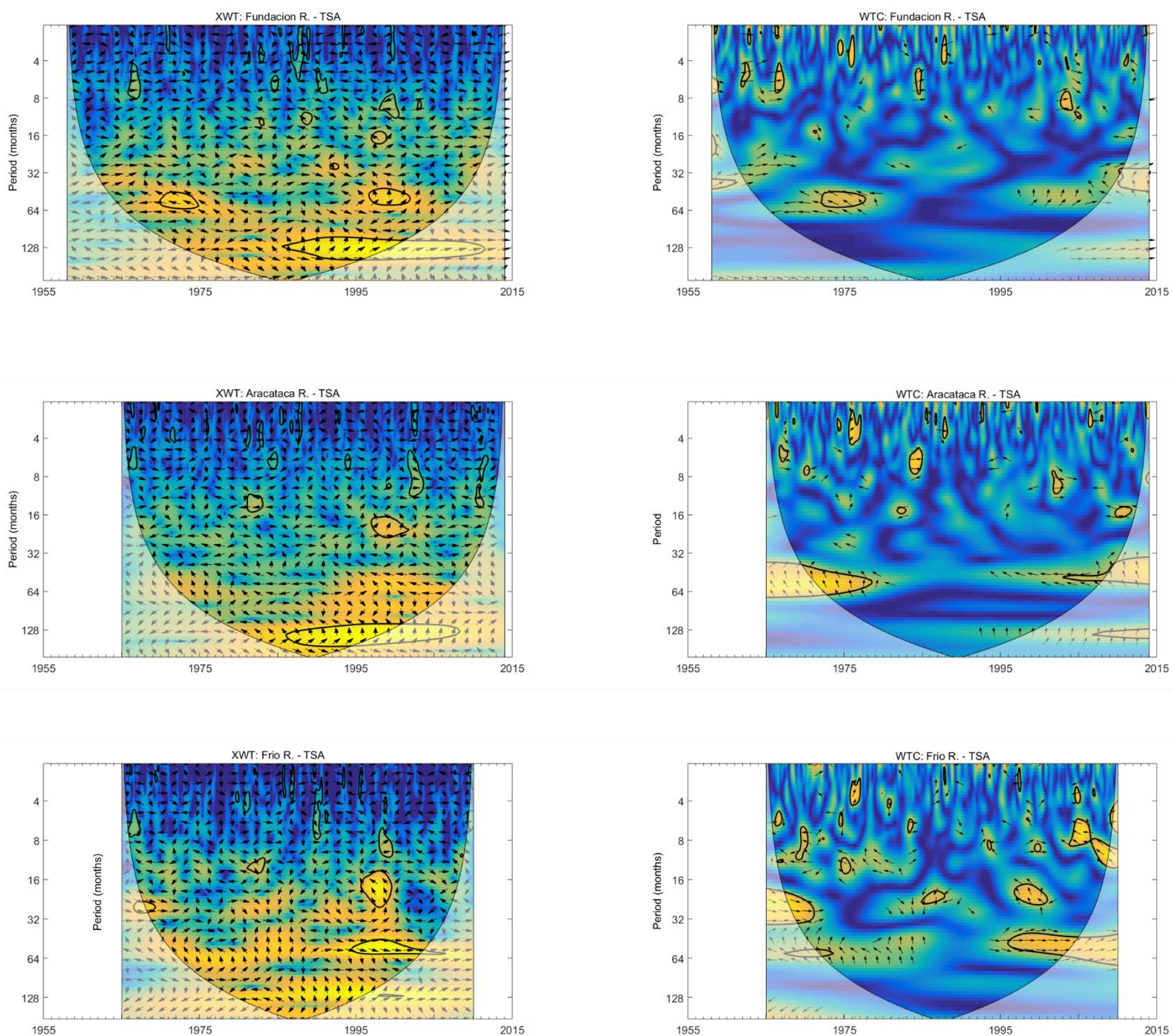

Fig. S9. Cross Wavelet Transform (XWT) and Wavelet Coherence (WTC) between TSA and the Fundación, Aracataca, and Frío rivers. 

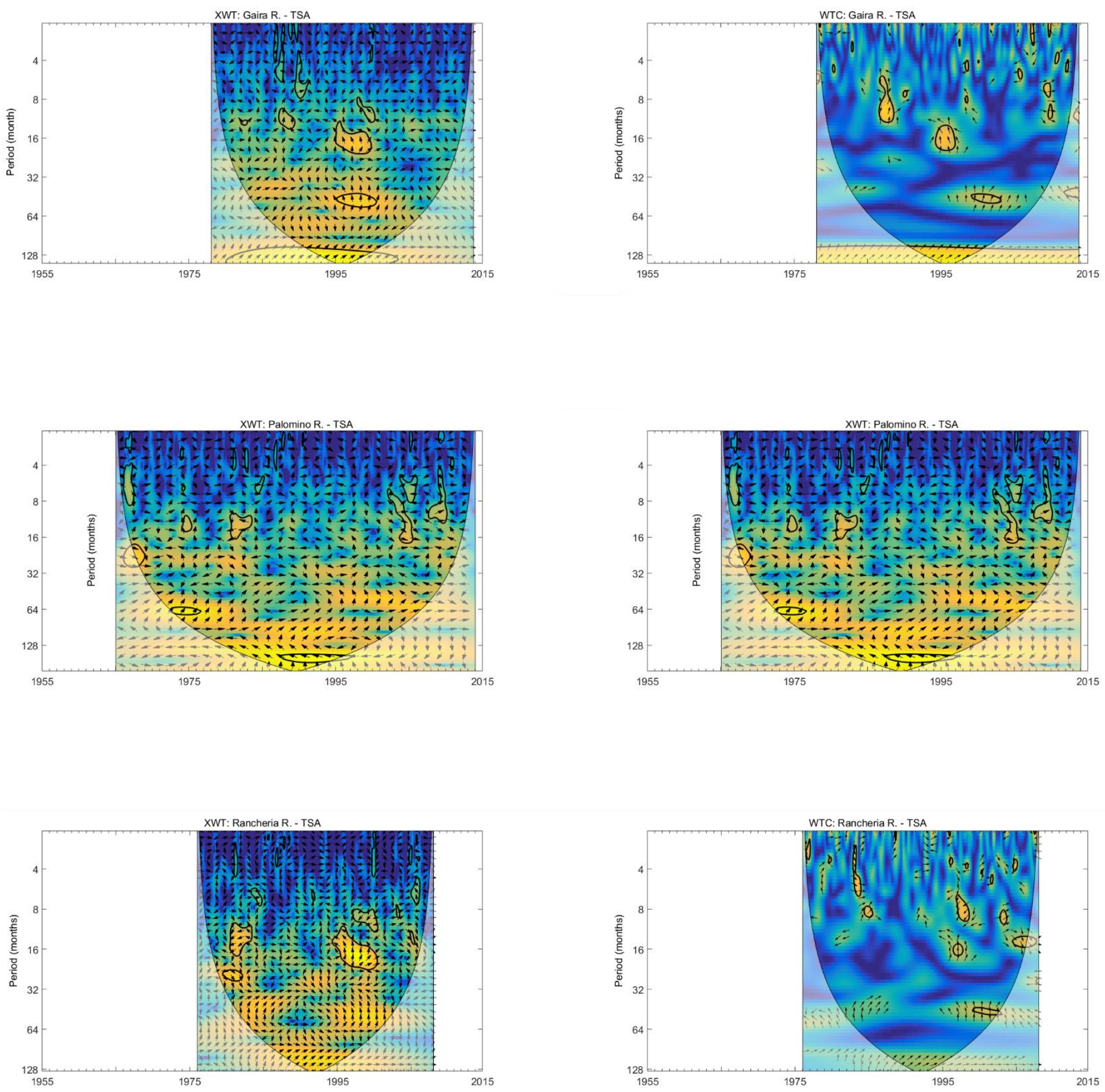

Fig. S10. Cross Wavelet Transform (XWT) and Wavelet Coherence (WTC) between TSA and the Gaira, Palomino, and Ranchería rivers. 